\title{
America in "British" History Textbooks
}

\author{
Srdjan Vucetic (University of Ottawa)
}

Paper prepared for presentation at the Transatlantic Studies Association 17th Annual Conference, University of North Georgia, Dahlonega Campus, 9-11 July 2018.

24 June 2018, approx. 10,000 words (52 footnotes), including Appendix ${ }^{1}$

Always far more special in London than in Washington, the so-called Anglo-American (a.k.a. UKUS) special relationship has greatly influenced British foreign policy for at least seven decades, and it continues to influence it under the conditions of 'Brexit' and the radical presidency of United States (US) President Donald Trump. This is most clearly evident in Britain's strategy and operations in security and military matters, including British nuclear deterrent, intelligence, and counter-terrorism. How do we explain this phenomenon? In a recent study, I have argued that the special relationship is rooted in a broader cultural infrastructure of British society. ${ }^{2}$ Using constructivist International Relations (IR) theory as my starting point, I examined a set of symbols and practices of everyday national life in contemporary Britain as a way of gauging the degree of consent for British foreign policy orientations vis-à-vis the U.S. What I discovered is that British national identity discourses, whether hegemonic or counter-hegemonic, have a tendency to configure 'America' as either complementary to, or an extension of, Britain and its interests. Neither 'France' nor more broadly 'Europe' came close to occupying this position.

This was a pilot study in which I focused solely on the year 2010. In this paper I expand on this project by examining aspects of continuity and change in the meanings of America in the discourses of British national identity in the entire period in which the special relationship has been claimed to exist. I do so using a corpus of text drawn from a sample of 'British' - that is, mostly English-school history textbooks published in roughly ten year intervals from 1950 to 2010. History textbooks are an apt choice for this purpose on both pragmatic and principled and grounds. Pragmatic, because history textbooks are a relatively accessible source of data, and because their content can be easily analyzed via text interpretation techniques. Principled, because they directly shape, and are shaped by, the discourses of nationhood. In fact, history textbooks are usually constructed and curated with an eye on national history curriculum, which, in turn, deliberately aims to inculcate a shared sense of national identity-who we are, where we come from and where we are going.

\footnotetext{
${ }^{1}$ For excellent research assistance, I am thankful to Abby Caldwell, Kazim Rizvi and Erin Van Weerdhuizen; for comments and criticisms, to Andrew Mycock, Robert Hendershot, and Steve Marsh. All errors remain mine.

${ }^{2}$ Srdjan Vucetic, 'British National Identity and the Anglo-American Special Relationship', Journal of Transatlantic Studies, 14: 3 (2016), 272-292.
} 
Analysis indicates the persistence of three reoccurring 'master images' or 'frames': America as a superior world power, America as the avatar of capitalist modernity, America as an ally and close friend. Certainly, the meanings of some of these shifted over time-the notion of Pax Americana owing something to Britain's sacrifice in World War II dissipated by the 1970s, for example. Yet there is a remarkable continuity in the construction of America as close and mostly positive. Differently put: while America oscillated between being subsumed under the Self and being an Other, France, Germany and 'Brussels' were always primarily Others. These findings, I would argue, are useful information for anyone interested in exploring the cultural and socio-political taproots of UK support for the special relationship in the postwar period.

The rest of the paper consists of five parts. The first looks at the purpose of history textbooks and history textbook research. The second part considers methodological issues, including the study's sampling rationale and the preference for a more inductivist discourse analysis and for human coding over machine coding. The third part presents the main results, and the fourth discusses them with respect to two literatures: on the special relationship and on the constructions of Europe in British school history. I conclude with a reflection on the value of history textbooks research in the scholarship on the cultural underpinnings of the special relationship and of foreign policy and international relations more generally.

\section{Why Textbooks?}

One of the central purposes of state-sponsored school history is to legitimize the state and nation - to explain how our present makes sense in light of our past. History textbooks are a key means for achieving this goal since they are designed not simply to present facts, but also to serve as 'sites of national memory'. ${ }^{3}$ One could also call them a transmission belt for citizenship. ${ }^{4}$ According to Foster,

in countries across the world textbooks remain potent vehicles to render a particular, 'official', version of the nation's past to young people. Nations rarely tell 'the truth' about themselves, rather in history classrooms and in history textbooks students often

\footnotetext{
${ }^{3}$ D. Porat, 'A Contemporary Past: History Textbooks as Sites of National Memory', International Review of History Education, 4 (2002), 36-55. On the relationship on memory and history in this context, see A. Mycock, 'After Empire: The Politics of History Education in a Post-Colonial World,' in M. Carretero, S. Berger, and M. Grever (eds), Palgrave Handbook of Historical Culture and Education (New York: Palgrave, 2016), pp. 391-440, p. 400.

${ }^{4}$ M. Apple and L. Christian Smith, eds. The Politics of the Textbook (New York: Routledge, 1991). Arthur, J., Davies, I., Haydn, T., Kerr, D., and Wrenn, A. Citizenship through Secondary History (London: Routledge-Falmer, 2001). M.C.R. Grever and J.C. van der Vlies, 'Why National Narratives are Perpetuated: Promising Reorientations in History Textbook Research,' London Review of Education 15(2), 286-301; and H. M. Madeley, History as a School of Citizenship Oxford (Oxford University Press, 1920).
} 
encounter narratives that dominant groups choose to select and remember as representations of the national story. ${ }^{5}$

Foster's observation is based on numerous empirical studies: textbooks around the world have long worked hard to turn students into co-nationals, following the scripts of nationhood provided by 'dominant groups'. ${ }^{6}$ For example, in the settler states of the so-called Anglosphere-Australia, Canada, New Zealand and the U.S. ${ }^{7}$-, indigenous students in primary and secondary schools have traditionally learned nothing about their own traditions, to say nothing about the history and legacies of dispossession and genocide. Instead, they have been have asked to learn about the achievements of European culture and civilization and of the successes of visionary Europeans who founded these countries. ${ }^{8}$ Racialized and ethnic minority students are exposed to similarly lopsided narratives, the outstanding case in point being an entire century of misinformation regarding slavery in U.S. textbooks. ${ }^{9}$ This is not merely an Anglosphere phenomenon of course. History textbooks in, for example, contemporary China also produce and reproduce mostly positive, feel-good stories about the nation's history while also cementing Han-centric views of the Chinese national identity. ${ }^{10}$

The apparent universality of these findings should not be surprising. The study of the national past in primary and secondary schools was part and parcel of the European nation-state model that has over the last two hundred years diffused around the world. ${ }^{11}$ One rationale for developing national mass education systems was to make sure that 'our children' learned 'our history', which, as Forster puts it, 'often is a watered-down, partial, sometimes distorted, and

\footnotetext{
${ }^{5}$ S. Foster, 'Dominant Traditions in International Textbook Research and Revision', Education Inquiry 2 (2011),1-19, p. 7.

${ }^{6}$ Carretero, Berger, and Grever 'Introduction: Historical Cultures and Education in Transition', in Carretero, Berger, and Grever (eds) (2016). Palgrave Handbook of Historical Culture and Education (New York: Palgrave), pp. 1-36, at p. 2, 16.

${ }^{7}$ S. Lightfoot, 'Selective Endorsement without Intent to implement: Indigenous Rights and the Anglosphere'. The International Journal of Human Rights, 16: 1 (2012), pp. 100-122. Also see S. Vucetic, The Anglosphere: A Genealogy of Racialized Identity in International Relations (Stanford: Stanford University Press, 2011).

${ }^{8} \mathrm{~A}$. Hickling-Hudson and R. Ahlquist, 'Contesting the curriculum in the schooling of indigenous children in Australia and the United States: From Eurocentrism to culturally powerful pedagogies' Comparative Education Review, 47 (2003), 64-89. M. Sheehan, 'The place of 'New Zealand' in the New Zealand history curriculum. Journal of Curriculum Studies, 42 (2010), 671-691. A. Clark, 'Teaching the Nation's Story: Comparing Public Debates and Classroom Perspectives of History Education in Australia and Canada', Journal of Curriculum Studies, 41: 6 (2009): 745-62.

${ }^{9}$ Compare 'How Texas Teaches History', The New York Times (Oct 21, 2015); S.J. Foster, 'The Struggle for American Identity: Treatment of Ethnic Groups in United States History Textbooks', History of Education, 28 (1999),251-27; and Lawrence Reddick, 'Racial Attitudes in American History Textbooks of the South', Journal of Negro History, 19:3 (1934), 225-265.

${ }^{10}$ Foster, 'Dominant Traditions', p. 13. Also see Y. Chu, 'The power of knowledge: A critical analysis of the depiction of ethnic minorities in China's elementary textbooks', Race Ethnicity and Education, 18 (2015), 469-487.

${ }^{11}$ Carretero, Berger, and Grever (eds), Palgrave Handbook of Historical Culture and Education. (New York: Palgrave, 2016), Part I.
} 
sometimes a fictional view of the national past based upon cultural, ideological and political selection' ${ }^{12}$

Research shows that state-sponsored history education frequently fails in transmitting national ideologies and identities to 'our children'. ${ }^{13}$ This is due to the power of 'pre-existing conceptions' and 'initial historical knowledge' as well as of familial and community teachings, all of which are sometimes in contradiction with state-sponsored history. ${ }^{14}$ Furthermore, statesponsored education is always in flux. In parts of the Euro-American world, for one, school history has undergone a profound change over the past sixty years thanks to the rise of the feminist movement, of Black Power, of decolonization, of post-colonial immigration, and of regional integration. International advocacy, such as the mandates of UNESCO and the Council of Europe, have had a significant influence as well. Elsewhere, 'democratic backsliding', 'the rise of nativism' and corollary developments are at play, and are accordingly moving history textbooks away from 'liberal' or 'globalist' themes and towards 'patriotic' ones. ${ }^{15}$

School history is now routinely enveloped in 'history wars' and even broader 'culture wars'. ${ }^{16}$ According to Philips, the modern history of history wars in the UK began in the 1960s in a confrontation of political and social historians over the degree to which the next generation of textbooks should emphasize issues of class, race, gender and various 'critical' perspectives that accompany them. ${ }^{17}$ Another war was over appeals for multi-national ('not just English') history, which subsequently spilled over to similar contestation over the need for multicultural, European, and global approaches. History wars marked the 1970 s and the 1980 s as well. For instance, as UK curriculum-makers began to turn toward the interrogation of primary sources, there emerged a vigorous debate about the purpose and distinctiveness of history ('The New History') vis-à-vis other fields (women's studies, for example) as well as about the putative trade-offs between 'skill' on the one hand and 'knowledge' and 'content' on the other. Devolution policies, which began in the late 1980s, naturally caused further rethink of history

\footnotetext{
${ }^{12}$ Foster, 'Dominant Traditions', p. 13.

${ }^{13}$ D. Porat, “'It's Not Written Here, but This is What Happened': Students' Cultural Comprehension of Textbook Narratives on the Israeli-Arab Conflict", American Educational Research Journal, 41 (2004), 963-996; M. Grever, T. Haydn, and K. Ribbens, 'Identity and School History: The Perspective of Young People from the Netherlands and England', British Journal of Educational Studies, 55 (1) (2008), pp. 1-19. Also see Haydn, Terry and Harris, 'Pupil Perspectives on the Purposes and Benefits of Studying History in High School: a View from the UK'. Journal of Curriculum Studies, 42(2) (2010): 241-61.

${ }^{14}$ Carretero, Berger and Grever, 'Introduction', p. 19; R. Andrews, C. McGlynn, and A. Mycock, 'Students' attitudes towards history: does self-identity matter? Educational Research, 51 (3) (2009), pp. 365-377; and Haydn, Terry and Harris, 'Pupil Perspectives on the Purposes and Benefits of Studying History in High School."

${ }^{15}$ Deutsche Welle, "Turkey, Hungary and Poland: The politics of school textbooks," October 19, 2017. http://www.dw.com/en/turkey-hungary-and-poland-the-politics-of-school-textbooks/a-41032191

${ }^{16}$ Carretero, Berger \& Grever, 'Introduction', p. 2.

${ }^{17}$ Phillips, R. (1999). 'History teaching, nationhood and politics in England and Wales in the late twentieth century: a historical comparison,' History of Education, 28 (3), pp. 351-363.
} 
curricula that lead to, among other things, England's adoption in 1991 of its first 'National Curriculum' for history. (In England, the main battlefields are curriculum reforms rather than textbook production partly because of the existence of multiple examination boards who often recommend different textbooks.) Suffice it to say, curricula in the UK are being transformed yet again in the wake of both the Scottish independence referendum and the Brexit vote.

One way to observe history wars in UK history education in real time is to follow the recent and ongoing debate over the meanings of the British Empire-from the controversy surrounding England's 2013 National Curriculum guidelines to the 2017 'Ethics of Empire' uproar. ${ }^{18}$ As Mycock observes, virtually every state that once did the formal colonizing suffers from a condition variously called 'post-colonial amnesia', 'conspiracy of silence', 'post-colonial melancholia' and 'selective myopia'. This, as he defines it, is a social-cognitive-affective structure that prevents post-colonizing states and societies from critically evaluating their colonial histories. ${ }^{19}$ For example, many if not most UK history educators still insist on, first, separating the domestic from the imperial, and, second, on depicting the latter as both universal and, on balance, beneficial. ${ }^{20}$ Similarly, while 'slavery' appeared as a National Curriculum topic in 1990, it was in fact not covered in curricula and textbooks until the late 2000s. ${ }^{21}$ The same goes for postcolonial perspectives: though they have long been articulated from either the former colonies or from within the post-colonial Britain, these are almost entirely absent. ${ }^{22}$ School history perspectives on the British Empire are yet to catch up with the perspectives advanced in the field of 'new imperial history', for one. ${ }^{23}$

In sum, history textbooks are important sources of the symbols and discursive practices that purvey a particular view of a nation's past. In addition to configuring the meanings of 'home,' textbooks also shape student's understanding of key self-other relations 'abroad' - that is, of their country's main friends and allies, rivals and enemies as well as of key international

\footnotetext{
${ }^{18}$ See, respectively, R. Guyver, 'Michael Gove's History Wars 2010-2014: The Rise, Fall and Transformation of a Neoconservative Dream,' Agora 49 (4) (2014), 4-11; and Ethics and empire: an open letter from Oxford scholars, December 19, 2017 https://theconversation.com/ethics-and-empire-an-open-letter-from-oxford-scholars-89333 shame, atonement and denial as well as key UK institutions and laws.

${ }^{22}$ S. Grindel, 'The end of empire: colonial heritage and the politics of memory in Britain', Journal of Educational Media, Memory and Society, 5: 1 (2013), 33-49; M. L. Wilkinson, 'The concept of the absent curriculum: The case of the Muslim contribution and the English National Curriculum for history', Journal of Curriculum Studies, 46(2014), 419-440.

${ }^{23}$ See T. Ballantyne, 'The Changing Shape of the Modern British Empire and its Historiography', The Historical Journal, 53 (2010), pp. 429-452 and T. Van der Vlies 'Echoing National Narratives in English History Textbooks', in: Carretero M., Berger S., Grever M. (eds) Palgrave Handbook of Research in Historical Culture and Education. (London: Palgrave Macmillan, 2017), 243-258.
} 
institutions, global governance structures, transnational advocacy groups and the like. ${ }^{24}$ This is why it matters for us to understand how British history textbooks narrate 'America'.

\section{Which Textbooks?}

To build a corpus of textbooks, I based my research on the work I conducted under the auspices of the Making Identity Count (MIC) - a large multi-national project revolving around a series of discourse analyses of select national identities. ${ }^{25}$ I began with 'popular' textbooks on modern English or British history that were most likely to have been used at the time in private and state secondary schools across the UK, but primarily those in England. This explains the title of the paper in which the adjective 'British' appears in quotation marks. In addition to the fact that England, Northern Ireland, Scotland, and Wales did not share a common educational program in British history in the period under study, the textbooks selected were either produced in England or centered on England. However, I am not using 'English' in this context because, first, some of the textbooks selected for analysis were probably popular in Northern Ireland and Scotland as well. Second, as other researchers have noted, English textbooks in this period have had a tendency to construct 'the political actorship and identity' as British, not English. ${ }^{26}$

I acknowledge that history teachers in the UK began to use textbooks in the history classrooms in large numbers only at after the introduction of history General Certificate of Education Exam (GCSE) and the National Curriculum initiative in the late 1980s. ${ }^{27}$ That said, the fact is that numerous textbooks - and 'topic-books' - existed and circulated even before the specification of curriculum needs, purveying historical information to teachers and helping students prepare for standardized tests. ${ }^{28}$ With this in mind, for each decade under study I selected two textbooks that would have been popular among students studying for history GCSE and history A Level exams (more advanced qualifications generally required for university entrance) or their closest historical equivalents (CSE/O level and A level) - that is, for students between the ages of 14 and 19. I used only the hard copies, not the CDs and e-books that became available at the

\footnotetext{
${ }^{24}$ Foster, 'Dominant Traditions', p. 13.

${ }^{25}$ More information on the project website: https://nationalidentitydatabase.wordpress.com/ This database is likely to be of interest to textbook researchers, too. for As Van der Vlies has argued, narrative continuity and discontinuity in history textbooks are predicated not simply upon state intervention in history curricula, but also, intertextually, on the broader circulation of popular cultural forms, such as poems and movies. T. Van der Vlies, "Echoing National Narratives."

${ }^{26}$ Inari Sakki, 'Raising European citizens: Constructing European identities in French and English textbooks', Journal of Social and Political Psychology, 4 (2016), 444-472, at p. 466, n.1.

${ }^{27}$ Nicola Sheldon, 'History Textbook from 1965-2010', The History in Education Project, June 2011, pp. 1-2. Available at www.history.ac.uk/projects/research/history-in-education

${ }^{28}$ Marjorie Reeves, Why history? (London: Longman, 1980), p. 52, 67-8.
} 
turn of the millennium. ${ }^{29}$ In the earlier period under study, approximately from the 1950s through the 1980s, history textbooks tended to have a longer shelf life than in the later period. As a general rule, I selected the editions published in years nearest to the beginning of the decade-1958 or 1959 for the 1960s, for example. Also, if one of the two textbooks covered only a short period of history and/or was exceptionally short, as in the 1990 s sample, I added a third textbook.

Given that reliable data on textbook usage are non-existent for most years under study, I determined popularity in a given time period by combing through the materials made available by the History in Education Project at the Institute of Historical Research ${ }^{30}$ and the Historical Association $^{31}$; contemporary and historical reviews and discussions in the professional journals for history teachers (Teaching History, established in 1969, and History of Education Review, 1971), and in other specialist literature. ${ }^{32}$ In addition to 'usage', my other selection criterion was sufficient treatment of 'Modern Britain', a popular exam theme in secondary school for most of the period under study. I defined 'Modern Britain' simply as 'the preceding hundred years', which I think is defensible from the perspective of research on knowledge acquisition and specifically the finding that learners are more likely to privilege events 'occurring in the last 100-150 years'. ${ }^{33}$ Explicitly England-focused were included as well. For example, I allowed for the second edition of Barker Alan, Aubyn, and Ollard's A General History of England 1832-1960, but analyzed only the chapters covering the period from the 1860 s onwards. ${ }^{34}$

Together, the selection criteria yielded a 'primary corpus' of 15 textbooks. As a check on generalizability of the findings, I created a 'secondary corpus' consisting of five popular 'nonhigh school' British history textbooks in use during the same period-each of these catered either to primary school students, university students, or the general audience but not explicitly to high school students. Table 1 lists all twenty textbooks by author(s), title, edition and the decade of usage.

\footnotetext{
${ }^{29}$ Medrano selects one textbook for each decade between the 1950s and 1990 that adhered to O-Level and GSCE examination guidelines, but his sample (of five textbooks) does not overlap with mine, however. Juan Diez Medrano. Framing Europe: Attitudes to European Integration in Germany, Spain, and the United Kingdom (Princeton, N.J.: Princeton University Press, 2003), p. 271, 275.

${ }^{30}$ D. Cannadine, J. Keating, and N. Sheldon, The Right Kind of History: Teaching the Past in Twentieth-century England (Baskingstoke: Palgrave, 2012).

${ }^{31}$ For details, see www.history.org.uk

${ }^{32}$ K. A.Crawford, and S. J. Foster, 'The political economy of history textbook publishing in England', in J. Nicholls (ed.), School History Textbooks Across Cultures: International debates and perspectives (Oxford, UK: Symposium Books, 2006), 93-105. It was only after I assembled my sample that I discovered the Georg Eckert Institute for International Textbook Research and its excellent catalogue of textbooks.

${ }^{33}$ Carretero, Berger and Grever, 'Introduction', p. 20.

${ }^{34}$ Alyssa Maraj Grahame did the selection for the 2000s, I did the rest.
} 
The coding proceeded on the basis of the interpretive recovery of national identities and identifications via discourse analysis of popular texts developed in the MIC project. The basic unit of analysis is 'the identity category', defined here the classifications attached to the nation and members of the nation. These categories could be political, moral, cultural, historical, geopolitical, religious, ethnic, racial, gendered, or miscellaneous-including the category of 'significant Others'. Only the basic text was coded, not primary material excerpts or visuals.

\section{Table 1: A Sample of British History Textbooks, 1950-2010 ( $\mathrm{N}=20$ )}

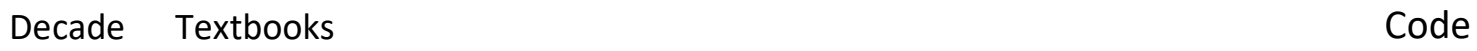

Notes: Code plus page number is used for citation in the section below: e.g. CM-213. See Appendix for full bibliographic details.

For the purposes of the present analysis, the focus was on the categories from paragraphs, sentences or sentence clauses with 'America' or 'American' in relation to contemporary Britain. Each category was coded in terms of both valence (positive, negative, neutral, ambiguous) and hierarchy (America as either more advanced or lagging behind culturally, economically or 
politically). In line with project guidelines, coders performed the same codings for a number of significant Others that similarly emerged in the same body of text, from 'Europe' to 'Ireland' to 'Victorian Britain'. This technique enabled direct multi-way comparisons and a rank-ordering of Britain's most significant Others. In light of the interest in the UK-US special relationship, close attention was paid any nuanced differences between America/American on the one hand and Britain's political or diplomatic relations with America on the other.

The analysis was conducted by either by myself of by coders I trained in the discourse analytic procedures of the MIC project. We did not follow a codebook but allowed the national identity categories to emerge inductively from the text, without pre-theorising content. ${ }^{35}$ Once the categories were collected I clustered them into stereotypical 'master images,' a.k.a. 'gestalts. '36 Rather than a sum of specific identity categories, these are integrated mental constructs or 'frames' that convey information and experience-based knowledge about the Other's capabilities (stronger/weaker), intentions (friendly/hostile), status within international society (superior/inferior) and trustworthiness (high/low). Images about the Other, which like identity discourse are at once cognitive and affective, are ubiquitous in all human societies as they help actors situate themselves in the social world, thus enabling individual and institutional action and interaction, including in foreign policy.

This approach undertaken here is a departure from the existing analyses of the constructions of America in British history textbooks, which tend to be based on the pre-determined choice of extracts. For example, in their History Lessons, Lindaman and Ward examine what America means in British and other foreign textbooks through a string of excerpts on major historical events and themes specified by the editors themselves. ${ }^{37}$ While in many ways eye-opening due to a wide cross-national comparative scope, their account nevertheless offers only a small slice of available meanings. ${ }^{38}$ Thanks to its inductivist orientation, the present approach casts the analytical net much more widely to consider all relevant discourses, narratives, and strategies

\footnotetext{
${ }^{35}$ For details, see Srdjan Vucetic, “A How-to Guide for Project Contributors," December 2015, Available at https://nationalidentitydatabase.files.wordpress.com/2016/01/srdjan-how-to.pdf On where this project falls in terms of (positivist) validity-reliability trade-offs, see Bentley Allan, 'Recovering Discourses of National Identity,' In Ted Hopf and Bentley B. Allan, eds. Making Identity Count: Building a National Identity Database (Oxford: Oxford University Press, 2016t), pp. 20-44. Many researchers in sociocultural history and comparative education have analyzed textbooks via discourse analysis, either alone or in conjunction with other methodologies. See, for example, Sakki, 'Raising European citizens'.

${ }^{36}$ Richard K. Herrmann, 'Perceptions and Image Theory in International Relations." In Huddy Leonie, D. Searsan and J. Levy, eds. The Oxford Handbook of Political Psychology (Oxford: Oxford University Press, 2013) pp. 403-433.

${ }^{37}$ Dana Lindaman and Kyle Ward, History Lessons: How Textbooks From Around the World Portray U.S. History. (New York: New Press, 2004).

${ }^{38}$ Their analysis also deals with only four British textbooks published between 1998 and 2001, one of which is a treatment of the Tudor Britain.
} 
of representation of America in British history textbooks. It also does this in a properly longitudinal fashion, across seven time periods.

\section{Textbook America}

British school history is a heterogeneous object that has undergone dramatic changes since the middle years of the twentieth century. Yet, when it comes to the image of America, my analysis of twenty textbooks published over the course of seven decades points to continuity, not change. To begin with, simple frequency counts of identity categories indicate that America is Britain's most significant Other. America is a top category in thirteen out of fifteen textbooks in the primary corpus, with 'Europe' dominating only in two textbooks (BA, SC). The second most frequent category is 'Europe', either as a stand-alone, vague category, or in the more recent textbooks as the European Economic Community, EEC, or the European Union (EU). Among specific European countries, France and Germany are configured as Others more frequently than any other European nation. 'The British Empire/Commonwealth' and 'the Western' were also salient, typically as extensions of the British Self rather than as Others. ${ }^{39}$ Analysis of the secondary corpus affirms these findings.

The other main finding is that 'textbook America' coalesced into four mainline ('master') images or frames: America as a superior peer, America as the avatar of capitalist modernity, America as a friend and ally, and America as an exceptional democracy. For the reasons of space, I concentrate only on the first three. What is striking is the consistency with which each three appeared and reappeared in textbooks published over the course of more than sixty years. Let us consider each image in turn.

The superior world power. According to the textbooks published from the late 1940s through the late 1950s, Britain had every reason to feel good about itself vis-à-vis its international peers. The main reason was World War II: the British were once again the victors, with the Germans once again the vanquished (RA-513). The feat is all the more significant in light of the fact that Britain 'stood alone' in combat against the Nazis after the surrender of France in June 1940.

The other main reason was the Empire, which was still strong and stable. 'Britain and the Dominions... are the areas where democracy has proved reasonably successful and where men

\footnotetext{
${ }^{39}$ For more on these counts see a series of "British national identity reports, 1950-2010," that I authored or coauthored under the auspices of the MIC project: https://srdjanvucetic.wordpress.com/research/id/ My use of the clunky phrase Empire/Commonwealth is meant to capture the variation in the ways the British world was configured over time. For one, only textbooks published in the 1940 s evaluated the Empire positively. All others either minimized imperialism or declared it an economic and/or moral folly. Example: Winston Churchill declared, 'I see little glory in an Empire which can rule the waves and is unable to flush its own sewers' (MA-93).
} 
have been the most free'; as such, they were 'the best hope for the future progress of mankind', especially in the new nuclear era (CM-1031; also see BA-282; ST-330).

While victory and the empire were ubiquitous in later textbooks, too-even in the 1990s, British students read that '[at] the end of the war Britain was the only imperial and West European state with the status of a world power' (KM-5)-, the dominant perspective on British greatness was that of nostalgic contemplation. Already in the late nineteenth century-the 1870 s to be specific - it was evident that 'Britain would eventually be caught up and passed' in medicine, steel production, manufacturing, financial capital and most new technologies (CM896; BA-65; TI-189, 226, 243, U2-16; WR-292).

World War II thus merely accelerated Britain's decline. Frequently mentioned manifestations of this new reality were Britain's dependence on American power in the war (WA-285) and, in the postwar period, subordination to the Americans in the nuclear domain (BA-283; U1-200; WE596) and in the domain of 'Anglobal' governance:

In Greece, Americans acted as observers during the Greek elections and, in February 1947, when Britain was no longer able to afford support, President Truman announced that America would take over this commitment in Greece as part of a policy to aid 'free peoples' against totalitarianism (U1-198).

British and Commonwealth units served in Korea but most of the troops and equipment were American (U2-218).

The remarkable continuity of this narrative is evident in the following selection of excerpts taken from textbooks published in, respectively 1977, 1979, 1980, 1987, 1997, and 2008:

The war of 1939-45 radically altered Britain's position in the world. She was no longer a Great Power, in a globe in which only the U.S.A and the USSR were Great Powers. She was dependent on American credit for survival (HI-282).

The 'Big Three' powers, however, were in fact the big two-the USA and the USSR-plus Great Britain (SC-55).

After the Second World War, the world only knew about two main powers, the United States and the Soviet Union (WE-584).

However financially indebted to the Americans the British might be, there were those who argued patriotically, but not unrealistically, that she could still hold her head high. Thus The Economist wrote: Our present needs are the direct consequence of the fact that we fought earliest, that we fought longest, and that we fought hardest. In moral terms we are creditors (MA-378). 
The USA and the USSR had emerged from the war as the two superpowers. In the 1930s other countries such as Britain and France had been as important in international affairs. However, the war had finally demoted Britain and France to a second division (CT-253).

Britain's imperial decline was symbolised by the events of 1947, with the decision to withdraw from India, and the humiliating dependence upon financial aid from the United States (CR-144).

The image of the World War II-induced decline and the corollary dependence on the US was subject only to minimal variations. Some authors of older textbooks were more likely to begrudge the too-smooth rise of American power after 1945, implying that Pax Americana was predicated on Britain's wartime sacrifice. Others located decline in other factors, including the decisive role of World War I. Example: the German U-boat campaign 'almost brought Britain to her knees' before the US joined the fray; 'Ever since the war the United States had enjoyed a standard of living that was the marvel and the envy of the rest of the world (U1-137, 146; U-67; WR-37; WE-523; cf. WA-286, 357).

The avatar of capitalist modernity. US superiority vis-à-vis Britain was never absolute. Several textbooks constructed the US as a source of new forms of politics and policy (CP-2). Yet, many of these forms were morally and politically unattractive to the British. 'Race relations' are one case in point; universal healthcare another; in each case, Britain had nothing to learn from America, and America had everything to learn from Britain. The tendency to critically evaluate aspects of the American society was also more common in the more recently published textbooks.

With respect to industrial capitalism, there was no contest, however. A textbook published in 1960 explains that the rise of American power had everything to do with the advent of the 'third stage of the Industrial Revolution', namely '[a]tomic energy, electricity, and internal combustion engine...aluminum, steel, concrete and plastic' (BA-65). British decline relative to the US was a century old phenomenon that had to do with factors including the inefficient use of capital, lower productivity, short-termism of British managers, traditionalism (a.k.a., the relative lack of 'social depth of demand') and the pervasiveness of 'gentlemen's agreements' as opposed to formal rules (MA-54, 284-8, 295).

No textbook missed an opportunity to comment on the size and scale of Britain's transatlantic competitor: 'Around 80 per cent of the vacuum cleaners sold in Britain were made abroad, one American brand leading many people still to talk of 'hoovering the carpet', irrespective of the make of vacuum cleaner they employ' (MA-335). And when the Americans 'stopped buying and lending abroad...the Great Slump reached Britain and spread round the world' (U1-146). 
As the leader of the modern world, America was a useful benchmark to evaluate the sensibility of British policies during the Cold War; why, for one, would 'Britain's defence expenditure in 1952 [be] higher in per capita terms than that of the United States' (KM-95)? Of all the authors in the primary corpus, the most critical of British policies is Trevor May. Tellingly, however, two of his main reflections on British decline are through American voices:

If Britain was the first country to enter an industrial world, is it possible that she might be the first to enter a post-industrial one? Such a possibility was discussed by the American economist John Kenneth Galbraith in a BBC interview in 1977: 'Your real problem is that you were the first of the great industrialised nations, and so things happen here first. You are living out the concern for some more leisurely relationship with industrial life that the other people have been discussing for 50 years or more'. In the following year, the London correspondent of the Washington Post wrote that 'Britons...appear to be the first citizens of the post-industrial age who are choosing leisure over goods on a large scale'. And in the last week of the decade, the Sunday Times wrote: 'As the Seventies began Britain exported $£ 150$ worth of manufactures for every $£ 100$ we imported. Today we export just $£ 115$ for every $£ 100$ of imports. We have become self-sufficient in North Sea Oil, but the envy of our industrial rivals has given way to more practical sentiments; selling us their cars, calculators, video recorders, and digital watches. Pessimistic commentators argue that Britain's relative decline may become an absolute decline, as swathes of our manufacturing industry become obliterated by foreign competition. But if the balloon does go up, we shall at least be able to watch and record it in colour, and time it to one-hundredth of a second' (MA277).

As well as having social and economic ambitions, politicians (and others) have diplomatic ones. Britain might have solved her economic problems more easily had she accepted sooner the fact that she had emerged from the war a greatly diminished power, no longer in the same rank as the Soviet Union or the United States. Her leadership of the Commonwealth did not prove an adequate counterweight. In 1962 the former US Secretary of State, Dean Acheson, declared, 'Britain has lost an empire, she has not yet found a role'. That role might have been the leadership of a new Europe, but Britain awoke late to the idea of a European Community, and did not in fact enter the European Economic Community until 1973. Politicians found it hard to explain to the public Britain's economic, strategic and global position. Not only did they promise more than they could perform; the public demanded more than it was prepared to pay for (MA- 414). 
In this reading, the British, the ruling elites and masses alike, were victims of their own historical success as well as their own illusions of grandeur.

The only other great power that comes close to America on the modernity front was Germany. The beloved National Insurance Act of 1946, explains a textbook from 1960, was essentially an adaptation of German social legislation introduced in the Bismarck era (BA-151). Indeed, '[i]n 1908, Lloyd George went to Germany to study the practical details of their system of social insurance' (CR-19). German musicians historically influenced English ones (ST-287), and the West German plastic industry impressively re-assumed its world-leading position within eight years (ST-323). By the 2000s, Germany was the most important country in Europe (LY-168) and one of the world's leading economies (LY-24).

The French Other can be found in this rubric, too, albeit as an exception that proves the rule: 'Even France was outpacing us in motor vehicle production' (TI-170, italics added). None of the textbooks sampled, not even those from the Attlee years, showed any interest in French dirigisme, or state-led economic development, as a model for negotiating capitalist modernity. To the extent that Britain imagined its capitalism as 'liberal,' 'market-oriented or 'Anglo-Saxon', this finding, too, helps explain the favourable attitude towards America relative to Britain's European peers.

Friend and ally. Apart for select 'old Commonwealth countries', Britain viewed itself as having only one close friend and close ally: the US. This was evident in all textbooks that mentioned either diplomacy or America. Five textbooks deployed the term 'special relationship', and did so either positively or neutrally (MA, LY, KM, CT, SC).

Typically, this friendship/alliance/special relationship was presented as a function of 'military realities as well as on sentiment and diplomatic expediency' (SC-106). In all but two cases, the phenomenon was dated back to World War II and specifically to the Destroyers for Bases and Lease-Lend Agreements. The sole American-authored book foregrounded the immediate period after the war instead:

Knowing that the struggle with Communism was worldwide and that her own powers were limited, the United States expected Britain to shoulder its share of burden of peace-keeping not only in Europe but in the Mediterranean and in vast expanses east of Suez where responsibility came still came naturally to the British (WE-584-5)

But these military realities could have taken a different path. Two excerpts from Unstead:

During the critical years Britain remained the close ally of the United States; this was not necessarily inevitable because, from 1945 until 1951, there was a Labour Government in 
Britain and Labour had for long tended to be suspicious of America and sympathetic towards Russia (U2-216).

Russia's inflexible attitude drove Bevin to abandon his hopes of establishing good relations with the Soviet Union and to work ever more closely with the United States (U2-227).

The same author also emphasises personal friendships between select British prime ministers and American presidents-Roosevelt and Churchill, Kennedy and Macmillan-and even some generals, like Montgomery and Bradley (U1-184, 188, U2-246). When such friendships were not there, the alliance suffered-'President Truman had not previously shared the innermost secrets of the Anglo-American alliance, and for the time being, he had to rely upon the views of his States Department and Service chiefs' (U1-193). Same for when secrets were kept as opposed to shared, as in the Suez Crisis (U1-222).

The notion that the alliance was a function of shared culture and social ties was generally secondary to military and diplomatic goings-on. Exceptionally, one textbook located the origins of the Anglo-American friendship in the nineteenth century, citing British emigration and ideas about racial affinity as causes (WR-305). Looking at the same period, another put an accent on civil society connections ('many Americans saw Britain as a spiritual home') alongside common banking interests and shared imperial goals in the Far East (WE-450). In the same vein, a point was sometimes made that Churchill and/or Macmillan had American-not 'American-born' mothers (WR-446).

Crucially, not all textbooks equated the alliance with friendship, and most of them spelled out that Britain was a rule-taker. Faced with limited strategic choices, Victorian-era policymakers consistently appeased the Americans, from the 1850 Clayton-Bulwer Treaty onwards (WE-451). World War II only deepened the trend. Lend-Lease was 'a mixture of friendly generosity and hard-as-nails business dealing' (MA-370, also see U2-188; RH-253; WR-442), Roosevelt was suspicious of British intentions' (WE-571), and American trade policies were hypocritical:

The Americans adopted what in retrospect appears to be a curious double standard over questions of international trade. They violently objected to the British system of imperial preferences and to the sterling balances accumulated by Britain during the war; yet they felt entirely free to defend their own high tariff barriers at a time when they had no possible economic rivals (SC-59).

As one textbook from 1989 puts it, 'a high-level consensus remains at both elite and popular level about the Atlantic Alliance. Membership of the EEC commands wide acceptance, if little enthusiasm, and the same is probably true of the Commonwealth' (KM-108). 
To be sure, there were times when the Atlantic Alliance commanded little enthusiasm. If the British people had known that the British generals were so often sidelined during World War II, they would have shown more resentment towards those 'overpaid and oversexed' American troops stationed in the UK (WR-443). The US was not cheered on during the Vietnam War (WE600 ) or at Greenham Common, a twenty-year long and largely women-driven protest against the stationing of American nuclear cruise missiles at a Berkshire air base (a 'graphic example of the extraparliamentary protests against government policy that were a feature of late twentieth-century politics', as LY-237 describes it). As in the case of the superior world power image, the alliance and friendship with the US were not absolute.

\section{Images of Specialness}

Britain's 'textbook America' was at once more powerful (politically, economically and militarily), more advanced (economically and sometimes culturally), and therefore more respected in international society (as superpower and the leader of the West) than Britain itself. What is more, these images persisted throughout the period under study.

Select Empire/Commonwealth polities were configured as Britain's close friends in a similarly consistent fashion. All textbooks from the 1950s and 1960s were explicitly favourable to the 'old' Commonwealth, as were most textbooks published in later decades. Consider Richards and Hunt's Illustrated History, whose third or 1983 edition is in the secondary sample. There, the authors dedicate an entire chapter on Canada, Australia and New Zealand, arguing that "Britain's membership of the EEC has made trade with Commonwealth countries less important to her and has made serious difficulties for some of them" (RW-346).

However, America hardly lagged behind in closeness and trustworthiness to the 'neo-Britains' like Australia, Canada, and New Zealand. 'Most of the hard working-sturdy British men and women mainly emigrated to Australia and New Zealand, to Canada and to the United States, for Africa had not yet begun to exert its fascination upon white settlers' (U1-87, also see WA-285). Indeed, if we go by some of the textbooks in the sample, Churchill's mid-century argument about the "fraternal association of the English-speaking peoples" was not a fantasy. ${ }^{40}$

Beyond this Anglosphere circle, there was only France, but always as an ally, rather than a friend. Indeed, the surveyed textbooks configured Britain's relationship with 'Europe' as an extension of the French alliance, which in turn was understood as inseparable from the German

\footnotetext{
${ }^{40}$ For context, see Srdjan Vucetic, "The Fulton Address as Racial Discourse," in Alan Dobson and Steve Marsh, eds., Churchill and the Anglo-American Special Relationship (London: Routledge, 2017), 96-115.
} 
Question (SC-80, for example). One textbook presented Britain's position between Europe and America as zero-sum:

Britain's attitude to Europe at the end of the Second World War was haughty, and reflected feelings that were themselves a compound of sentimental attachment to the Commonwealth and a desire to foster the 'special relationship' which it was thought existed with the United States (MA-402).

Related, while the meanings of 'Europe' were always diverse, in politics the Anglo-European relationship was narrated as deeply fraught. 'Brussels', meaning the EEC and the EU, represented a centralising, anti-democratic force, with a historic tendency of anti-British behaviour, as epitomised in the figures of Charles De Gaulle and Jacques Delors (SC-299; WA64-5, 152). Indeed, only once the reasonable Georges Pompidou succeeded the intransigent de Gaulle, observed one textbook author, could Britain and France normally cooperate, the codevelopment of the Concorde supersonic passenger jet being an example (TI- 173, 255).

Existing research on how British history textbooks construct Europe and European integration largely confirms the findings. Consider Medrano's Framing Europe. First, unlike the equivalent German and Spanish textbooks, British textbooks never once constructed the EU as a desirable counterweight to US. Second, they were much more likely to see the EU as inefficient, overbureaucratized, unaccountable, and, especially 'threatening to national identity'. Third, the lack of identification with Europe was related to the strong identification with 'the lands and peoples of the British Empire'. ${ }^{41}$ Indeed, 'the hierarchy of proximity that one finds in Spanish and German contemporary history textbooks - Nation, Europe, the Rest of the world-is not so clearly delineated in British contemporary history'. ${ }^{42}$ Last but not least, Europe was never once presented as super-ordinate to Britain; quite the contrary. ${ }^{43}$

Sakki's analysis of history and civics textbooks published in England since the 1980s finds that Europe and specifically European integration carried a high degree of ambivalence-whether to be in or out or threatened or not. Among different facets of European integration only the economic side is presented as positive, while all others are evaluated as either neutral or, more commonly, negative. Indeed, 'in the English textbooks the story of European integration is either silenced or controversial', she concludes, and 'the British are portrayed as the outsiders of Europe'. 44

\footnotetext{
${ }^{41}$ Medrano, Framing Europe, respectively, pp. 253, 255,258, and Ch.8. 'Decline', in contrast, does not seem to be related to anti-EU frames, p. 254.

42 Ibid. 223.

43 Ibid. 225.

${ }^{44}$ Sakki, 'Raising European citizens', her sample of textbooks ( $\left.N=9\right)$ does not overlap with mine.
} 
The author's analysis of the temporal transformation of the English textbooks since the 1980s finds this ambivalence to be fairly constant. The following observation is entirely in line with the above discussion:

[t]he European integration process is approached through a metaphor of an island, and through two different kinds of geo-political positionings: Britain's difficult relations with France and its special relations with the United States. Europe appears as a French construction; it is objectified and personified in France and in its former president Charles de Gaulle. ${ }^{45}$

Sakki also finds that the history textbooks are harder on Europe than civics textbooks: while historians represent European integration as functional, they also construct Europe as 'difficult and ambivalent'. ${ }^{46}$ This is in sharp contrast to the equivalent French representations, which are less determined by the language of national interest instrumentality and more by references to a shared post-war collective memory, shared values and a common European heritage.

Equally relevant are the following conclusions in Sakki's study. One: 'The EU-US relations were characterized as an alliance in the English textbooks and as an economic rivalry in the French textbooks' ${ }^{47}$ Two: the French textbooks constructed Europe as a French project 'in light of the post-war context where France had lost its superpower status in world politics, and Europe was seen as a way of restoring it'. ${ }^{48}$

A similar claim might be made about British textbooks in relation of the positive construction of America. Britain spent much of the period under study declining relative to other states and fretting about that decline. An exceptionally special alliance with America could therefore be seen as a way of halting the decline since it provided Britain with a means to pursue a world power role even if involved some compromises on 'independence.' This would suggest that it is a desire for greatness that drives support for the view of the US as a cross between a friendly and superior Other on the one hand and an extension of the British Self on the other. From this perspective, Britain's 'textbook America' is partly about British's great power status, not simply about any number of individual or integrated stereotypical images.

Be that as it may, the findings presented in this paper remain important because images and identity discourses, as part of broader social knowledge, contain pre-conceptions that structure policy understandings, specifically by shaping what policies are taken-for-granted for both elites

\footnotetext{
45 Ibid.

46 Ibid. p. 463.

47 Ibid. p. 464.

48 Ibid. p. 456.
} 
and masses. ${ }^{49}$ This has direct implications for international affairs, because nations who continuously represent each other as friends are far more likely to develop loyalty and trust towards each other. ${ }^{50}$

As for the 'stickiness' of images, this is rooted in cognitive biases, a tendency to ignore, put aside or temporize contradictory pieces of information being a common one. Related, national identity discourses change slowly, if at all, because they are naturalised via everyday social representations and practices and also because they are distributed across so many individuals, especially among the masses. Indeed, from America's abrupt termination of Lend-Lease to the Suez Crisis to the Vietnam War to the Nixon Shocks to George W. Bush, there has been no shortage of uncertain, emotionally-charged and therefore potentially image-changing developments. However, it appears that successive generations of textbook authors refused to use any of these developments to significantly modify their textbook Americas. ${ }^{51}$ However, it could be that the real shock is only taking place at the time of this writing: the radical US presidency of Donald Trump. Either alone or in conjunction with 'Brexit,' the Trump presidency has led many commentators to lament the damage to, and even the collapse of, the so-called rules-based international order, of which the special relationship was a key part. One way for assessing the influence of this shift on Britain's perceptions of America would be to look at British-or just English?-history textbooks from the 2020s.

\section{Conclusion}

I have attempted to contribute to the study of the cultural and socio-political underpinning of the UK-US special relationship by analyzing how 'America' was constructed in British history textbooks from the 1950s to the 2010s. My main findings is a dependable reoccurrence of three mainline images: America as a superior peer, America as the avatar of capitalist modernity, America as an ally and close friend. While many constructions, both within and outside these

\footnotetext{
${ }^{49}$ For a literature review, see Srdjan Vucetic, 'Identity and Foreign Policy' Oxford Research Encyclopedia of Politics. Available at: < http://politics.oxfordre.com/view/10.1093/acrefore/9780190228637.001.0001/acrefore9780190228637-e-435> Accessed: 2 March 2018. For similar arguments but based on a different research tradition, see Medrano, Framing Europe, pp. 5-7, 65, 256-8.

${ }^{50}$ Felix Berenskoetter, "Friends, There are No Friends? An Intimate Reframing of the International," Millennium 35 (2007), pp. 647-76; and David Haglund, 'Is There a 'Strategic Culture' of the Special Relationship? Contingency, Identity, and the Transformation of Anglo-American Relations', in Alan Dobson and Steve Marsh, eds. Contemporary Anglo-American Relations: A 'Special Relationship'? (London: Routledge, 2013), pp. 26-51. ${ }^{51}$ Contrast this with controversial historians who argue that the special relationship is scheme to turn Britain in what George Orwell used to call 'Airstrip One': Joyce Kolko and Gabriel Kolko. The Limits of Power: The World and United States Foreign Policy, 1945-1954 (New York: Harper \& Row, 1972); John Charmley, Churchill's Grand Alliance: The Anglo-American Special Relationship 1940-1957 (New York: Harcourt, 1995); and Edward Ingram, "The Wonderland of the Political Scientist," International Security 22 (Summer 1997), 53-63.
} 
three images, shifted over time and across issue-areas, America was consistently evaluated as less distant and less negative than France, Germany, and more broadly Europe. Only the 'old' Commonwealth was comparable America on valence.

This is an important finding if we agree with those who argue that domestically held ideas influence the constitution of alliances, including the special ones. After all, policy-makers will find it easier to marshal domestic support for certain foreign policies when these are consistent with the prevailing notions of how we are, who they and others are, were, or aspire to be. But if a foreign policy is inconsistent with a country's identity discourses, decision-makers will find it hard to receive support for them from their publics and electorates.

Future research could consider British history textbooks published in the first half of the twentieth century or even before Queen Victoria's Diamond Jubilee. This study would be of use to those interested in the pre-World War II 'origins' of the special relationship since it would help localize the time period in which American superiority, leadership, and friendship all became taken for granted in British school history. ${ }^{52}$ Another promising research direction would be to expand situate these textbook-based observations against the equivalents derived from analyses of leadership statements, newsmedia, novels, cinema, television, public opinion, and other sources. The more we get to know about stereotypical patterns of Othering in the British society over time, the better our chances of understanding British foreign policy, including the persistent support for the special relationship.

\footnotetext{
52 I am one of those: Srdjan Vucetic, 'A Racialized Peace? How Britain and the US Made Their Relationship Special,' Foreign Policy Analysis 7: 3 (2011), pp. 403-421.
} 


\section{APPENDIX Textbook Selection and Textbook Bibliography ${ }^{53}$}

The four textbooks representing, respectively, the 1950s and 1960s were selected for their focus on 'recent British history', meaning dealing with England and/or 'Britain in the World' in the period from the middle years of the nineteenth century onwards. All four were used in grammar schools and secondary modern schools-retrospective names for academicallyoriented secondary school types - in England and Wales.

For the 1970s, which in England and Wales included the rise of comprehensive schools, I selected Titley's Machines, money and men, the first edition of what was then a path-breaking textbook covering social and economic history of Great Britain from 1700 to the 1960, and Larkin's English History for Certificate Classes, which covered the 1789-1939 period and catered to 'the examination work in English history studied by Grammar and Secondary schools up to G.C.E. Ordinary level...[and] students working to Advanced level' (p. 7). For this selection, 'tractability' played a role in the sense that I was unable to source, in either quick or reasonably inexpensive fashion, the following sources: R. J. Cootes' Britain since 1700 (Longmans, 1st ed., 1968), P. Mauger and L. Smith's The British People 1902-1968 (Heinemann, 1st ed., 1969) and J. Ray's Britain and the Modern World (Heinemann, 1st ed., 1969).

For the next decade, I went with C.P. Hill's British Economic and Social History, the fourth edition, and Sked and Cook's Postwar Britain: A Political History, the first edition. Both textbooks were widely used throughout the 1980s. Thematically they completed each other: the former focused on 'British economic life, in trade, industry, agriculture, and finance (p. 236), and the latter on political institutions and policies. Tractability played a role here, too, in the case of Paul Richardson's Britain, Europe, and the Modern World, 1918-1977 (Heinemann, 1977). I also 'audited' Tony Howarth's Twentieth century history: the world since 1900 (2nd ed. by Josh Brooman). Published by Longman, and 'by arrangement with the British Broadcasting Company' as a television series for schools, the Howarth textbook was probably the most popular history textbook in the 1980s but I did not use it here because of the dearth of British content-none of its 48 chapters covered exclusively Britain and only one of the corresponding BBC series programs was entitled 'Britain Alone', which was a mere section in Chapter 30.

For the 1990s, I selected, first, An Economic and Social History of Britain, 1760-1970 by Trevor May, a new textbook by Longman that appeared on the market in 1987; second, a short pamphlet by Peter Connolly and Barry Phillips, Britain 1900-1939, published in 1989 by Spartacus Educational Publishers; third, Consensus Politics from Attlee to Major by Dennis Kavanagh and Peter Morris, two professors of politics, published by Blackwell in 1989. I selected three items instead of two because the last two were short and covered non-

\footnotetext{
${ }^{53}$ To be placed on the author's website, https://srdjanvucetic.wordpress.com/publications/.
} 
overlapping twentieth century periods. All three aimed to help secondary school students with modal examination topics, such as 'the social problems of industrialization' and 'the return to gold in 1925' (May) or 'the mixed economy' and 'the welfare state' (Kavanagh and Morris). In retrospect, I would have replaced Connolly and Phillips and Kavanagh and Morris with a single secondary school textbook, specifically Howard Martin's Britain's since 1800: Towards the Welfare State published by Macmillan in 1988.

For the 2000s, the textbooks selected were Walsh's Modern World History, a full-colour, first edition core text for GCSE published in 1996, and Culpin and Turner's Making Modern Britain: British Social and Economic History from the 18th Century to the Present Day, a core text covering all GCSE British economic and social history syllabuses published by Collins Educational in 1997 (its first edition appeared in 1987). In the Walsh case, the focus was on the Britain chapters (Chapters 2 and 3, focusing on the 1906-1918 period) by Ben Walsh (2001), and in the Culpin-Turner case on the coverage of the twentieth century only.

For the 2010s, the selection was done by my collaborator Alyssa Maraj Grahame. She selected Access to History Britain 1945-2007 by Michael Lynch (2008) and AQA History AS: Unit 1 Britain, 1906-1951 by Chris Collier and Chris Rowe (2008). Both textbooks were used for exam specifications at GCSE (15- and 16-year-olds) and A levels (17- and 18-year-olds), which were, and are, qualifications for advancement in education in England and Wales.

Selection for the secondary corpus followed fewer rules other than evidence of high usage in history teaching. Two selections are elementary school (pre-K12) textbooks by Unstead, a wellknown twentieth century author; two are university-level textbook-one by Webb, the only American author in the sample, one by Williams and Ramsden-and one is an illustrated textbook used in both primary and secondary schools.

\section{Primary Corpus: 15 High School-Level History Textbooks}

Barker, William Alan, G. R. St Aubyn, and Richard Lawrence Ollard. A General History of England 1832-1960. 2nd ed. London: A \& C Black, 1960.

Carter, E.H., and R. A. F. Mears. A history of Britain 1876-1953. 2nd ed. Oxford: Clarendon Press, 1948.

Collier, Chris. AQA AS history Britain 1906-1951: unit 1. Ed. Sally Waller. Cheltenham: Nelson Thornes, 2008. 
Connolly, P., and Barry Phillips. Britain, 1900-1939. Southwick: Spartacus Educational

Publishers, 1989.

Culpin, C., and Brian Turner. Making Modern Britain: British social and economic history from the 18th century to the present day. London: Collins Educational, 1987.

Hill, C.P. British Economic and Social History 1700-1975. 4th ed. 1977.

Kavanagh, Dennis, and Peter Morris. Consensus politics from Attlee to Thatcher. 1st ed. Oxford : Basil Blackwell, 1989.

Larkin, Patrick John. English History for Certificate Classes 1789-1939. London: Hulton Educational Publications, 1964.

Lynch, Michael. Access to History: Britain 1945-2007, 1st ed. London: Hodder Education, 2008.

May, Trevor. An Economic \& Social History of Britain: 1760-1970. 1st ed. Harlow: Longman, 1987.

Rayner, R. A short history of Britain. Longman, 1948.

Sked, Alex and Chris Cook. Post-War Britain: A Political History, 1st ed. Sussex: The Harvester Press, 1979.

Strong, C., and Charles Frederick. History of Britain and the World, Book Five: The Twentieth Century and the Contemporary World. 2nd ed. [S.I.]: U.L.P., 1956.

Titley, D.P. Machines, money \& men. Hart-Davis, 1979.

Walsh, Ben. GCSE Modern World History. 1st ed. John Murray, 1996.

\section{Secondary Corpus: 5 Non-High School History Textbooks}

Richards, Denis and J.W. Hunt. An Illustrated History of Modern Britain 1783-1980. 3rd ed. Essex: Longman, 1983.

Unstead, R.J. A Century of Change Bk.4. London: A. and C. Black, 1963; reprinted with corrections 1967.

Unstead, R.J. The Twentieth Century: Looking at History Bk.5. London: A. and C. Black, 1966; Reprinted with corrections 1970. 
Webb, R.K. Modern England: From the 18th century to the present. 2nd ed. London: George Allen \& Unwin, 1980.

Williams, Glyndwr, and John Ramsden. Ruling Britannia: a political history of Britain, 1688-1988, 1st ed. London: Longman, 1990. 